\title{
A HUNGARIKUMOK SZEREPE A TELEPÜLÉSEK FEJLŐDÉSÉBEN
}

\author{
Tözsér Anett \\ Nemzetstratégiai Kutatóintézet; anett.tozser@nski.gov.hu
}

DOI:10.15170/TVT.2021.06.04.04

\begin{abstract}
Absztrakt
A téma nemzetstratégiai jelentősége okán, a Nemzetstratégiai Kutatóintézet célul tüzte annak vizsgálatát, hogy a hungarikumok milyen szerepet töltenek be az érintett települések fejlődésében. A szakirodalmi vizsgálat során nyomon követtük a hungarikum fogalom fejlődését, értékeltük a hungarikumok nemzetstratégiai jelentőségét, valamint kitértünk arra, hogy milyen hatást gyakorolnak a helyi és a nemzeti identitásra. A primer kutatás során kérdőíves vizsgálatot végeztünk el a Hungarikum Gyüjteményben szereplö olyan hungarikumok körében, amelyek valamely településhez kapcsolódnak. Arra kerestük a választ többek között, hogy a hungarikum mennyire határozza meg a településfejlesztés gyakorlatát, hogyan viszonyul hozzá a település vezetése és hogyan a lakosság. Az érintett szervezetektöl azt is megkérdeztük, hogy a hungarikum milyen mértékü hatást gyakorol a munkahelyteremtésre és az együttmüködésekre az adott településen és az adott térségben. Az eredmények azt mutatták, hogy ha a válaszadók véleménye szerint a hungarikum jelentősebb szerepet tölt be a településfejlesztésben, akkor a településen élőket is nagyobb büszkeséggel tölti el az adott érték. Az is kiderült, hogy a hungarikumnak a településfejlesztésben történő nagyobb mértékü hasznosítása mellett az adott érték a munkahelyteremtésben és a közösségépítésben magasabb területi szinten (nem kizárólag települési, hanem regionális, országos vagy akár nemzetközi szinten) is képes hatni.
\end{abstract}

Kulcsszavak: hungarikum, nemzeti érték, helyi identitás, nemzeti identitás, Kárpát-medence 


\begin{abstract}
Due to the national strategic significance of the topic, the Research Institute for National Strategy aimed to examine the impact of Hungaricums in the development of the affected settlements. In the literature review, we examined the development of the concept of Hungaricum, evaluated its national strategic significance, and discussed the impact of Hungaricum on local and national identity. During the primary research, we conducted a questionnaire survey among those Hungaricums in the Hungaricum Collection, which are related to a settlement. We looked for the answer to the question, among other things, to what extent the Hungaricum determines the practice of settlement development, how the management of the settlement relates to it and how the population. We also asked the organizations concerned to what extent the Hungaricum has an impact on job creation and cooperations in the given settlement and region. The results showed that if, in the opinion of the respondents, a Hungaricum plays a more significant role in the development of the settlement, the inhabitants are also more proud of these values. It also turned out that in addition to the greater utilization of Hungaricum in settlement development, the value can have an impact on job creation and community building at a higher territorial level (not only at the settlement level, but also at the regional, national or even international level).
\end{abstract}

Keywords: Hungaricum, national value, local identity, national identity, Carpathian Basin 


\section{Bevezetés}

Magyarország Alaptörvénye a magyarság egységétől vezérelve megállapítja, hogy a magyar nemzeti értékek megörzendő és egyedülálló értékek és azok védelme hozzájárul a nemzeti azonosságtudat kialakulásához és megszilárdításához (MAGYARORSZÁG ALAPTÖRVÉNYE, 2011. ÁPRILIS 25).

Magyarország Alaptörvényére utalva Tózsa István felhívta a figyelmet arra, hogy a 21. század nehéz megmérettetéseiben az értékek megőrzése nagy feladatot ró ránk. Nem adhatjuk fel értékeinket, az elödeink által ránk hagyott örökségünket, ugyanis közös értékeink adnak iránymutatást ahhoz, hogy tudjuk, honnan hová tartunk, mi is az életünk igazi értelme (TÓZSA 2019).

A hungarikum elnevezést méltán tekinthetjük a világon egyedi jelenségnek, hiszen az „olyan, $a$ magyarok vagy idegen népek által magyarnak vélt és a nemzettel azonositott anyagi, illetve szellemi értékeket értjük alatta, amelyek eredetüknél és hirnevüknél fogva magyar specifikumok" (ZENTAI 2015: 5). A 2012. évi XXX. törvény a magyar nemzeti értékekről és a hungarikumokról (továbbiakban: hungarikum törvény) kimondja, hogy a hungarikumokat és a nemzeti értékeket gyüjteni, ápolni, őrizni kell, mert az összetartozás és a nemzeti tudat erősítésében kulcsszerepet játszanak. Mindemellett be kell azokat mutatni, hiszen fontos szerepük van az identitás és az imázs kialakításában, ráadásul gazdasági haszon is származhat belőlük. Ezen kívül kiemelendő még a nemzetstratégiai szerepük is, hiszen a hungarikumok célterülete nem csupán Magyarországra terjed ki, hanem minden olyan közösségre, amelyet magyar emberek alkotnak (HTTPS://NET.JOGTAR.HU/JOGSZABALY?DOCID=A1200030.TV).

A hungarikum téma nemzetstratégiai jelentősége okán a Nemzetstratégiai Kutatóintézet célul tüzte ki a hungarikum mozgalom vizsgálatát, illetve annak feltárását, hogy a hungarikumok milyen szerepet töltenek be az érintett települések fejlödésében.

Első lépésben szakirodalmi vizsgálatokkal tártuk fel a hungarikum fogalmának értelmezését, a hungarikum törvény rendelkezéseit, valamint annak nemzetstratégiai jelentőségét. Ezen kívül kitértünk arra, hogy a hungarikumok milyen hatást fejtenek ki a helyi és a nemzeti identitásra.

A szakirodalmi szintézist kiegészítendő, kérdöives kutatást végeztünk azokon a településeken, ahol hungarikum található. Ennek alapján a Hungarikum Gyüjteményben jelenleg (2021 áprilisában) szereplő 76 hungarikum közül kiválasztottuk azokat az értékeket, amelyek településekhez kötődnek. Ezek közül is kiemeltük azokat, amelyeknek turisztikai hatásuk van vagy lehet. Ezt követöen azonosítottuk azokat a szervezeteket, amelyek felelösek a kiválasztott hungarikumok kezeléséért, majd ezen szervezetek vezetöinek, képviselőinek segitségével készitettünk el egy átfogó kérdöíves vizsgálatot. Összesen, az érintett településekhez kötődő 35 
szervezetet kértük meg kérdöívünk kitöltésére. A 35 felkért szervezet közül 30 töltötte ki a kérdöívet.

A primer kutatás során azt vizsgáltuk, hogy a hungarikumok hogyan, milyen mértékben és milyen módon (eszközökkel) hatnak leginkább egy település fejlödésére. Ezt a témát vizsgálandó, a kérdőives kutatás során az alábbi kérdésekre kerestünk válaszokat:

- A hungarikum mennyire meghatározó tényezője a településfejlesztésnek, hogyan viszonyul a település vezetése a hungarikumhoz?

- Hogyan viszonyul a lakosság a településükhöz, illetve a térségükhöz kötődő hungarikumhoz?

- A hungarikum milyen szinteken (települési, regionális, országos, nemzetközi) gyakorol hatást a munkahelyteremtésre, a vállalkozásokra, a civil szervezetekre, a közösségekre?

- Adott településen a hungarikum milyen mértékü hatást gyakorol a munkahelyteremtésre, a hungarikumra épülő vállalkozásokra, a települési önkormányzat, a vállalkozások és a civil szervezetek között kialakult együttmüködésekre?

- Mennyi munkahelyet jelent ez? A települések bevételének mekkora része származik azon vállalkozásokból, amelyek az adott hungarikumhoz kapcsolhatók?

- Hogyan és milyen mértékben gyakorol hatást a hungarikum az érintett térség (megye) munkahelyteremtésére, a vállalkozások létrehozására és az együttműködésekre?

- Hogyan és milyen eszközökkel lehetne nagyobb mértékben hasznosítani a hungarikumot a települési identitás erősítése érdekében?

A várható eredmények segítségével felhívhatjuk a települések és a szakmai szervezetek figyelmét a hungarikumok hasznosításával kapcsolatos további lehetőségekre és ezen értékek hasznosításából származó társadalmi és gazdasági előnyökre.

\section{A hungarikum fogalma, értelmezése}

A hungarikum törvényt megelőzően született fogalmi értelmezések eltérően fejezték ki a hungarikum fogalmát, mégis egységesen kizárólag anyagi termékekröl foglaltak állást. Az is látható e fogalmi meghatározásoknál, hogy ezeket elsősorban az agrár- és élelmiszeripari termékek vonatkozásában fogalmazták meg (SZABÓ 2012, ZENTAI 2015).

A hungarikumok védelméről szóló országgyülési határozat elsőként határozta meg jogi értelemben a hungarikum fogalmát. A korábbi értelmezésekhez hasonlóan azonban ez a jogszabály is az agrár- és élelmiszeripari termékekre helyezte a hangsúlyt. E szerint ezen értékek egyedien és egyedülállóan magyar különlegességek, azaz hungarikumok, amelyek számbavétele a mai felgyorsult, globalizálódó életünkben különösen fontossá vált. A hungarikumnak földrajzi, történelmi, nyelvi, néprajzi arculata van. Olyan sajátos magyar termékek, melyeknek tulajdonságai között lényeges és kiemelkedö a magyar nemzeti jelleg, és amelyek természeti adottságainkkal, öshonos fajtáinkkal, termelési-tenyésztési hagyományainkkal összefüggésben sajátosan magyar ismérvekkel rendelkeznek. A hungarikumok magyarságra jellemző mivoltukkal, különlegességükkel, minőségükkel jelentősen öregbítik hírnevünket, növelhetik megbecsülésünket szerte a világon (77/2008. VI. 13. OGY HATÁROZAT A HUNGARIKUMOK VÉDELMÉRÖL).

A 2012-ben megszületett hungarikum törvény már pontosan rögzítette a hungarikum meghatározását. A törvényben olvasható definíció többlettartalommal rendelkezik az előzőekhez képest, hiszen a termékelnevezés már kiegészült a szellemi és kulturális javakkal. Mindezeket összefoglaló néven értékeknek nevezik. Ezzel összefüggésben a törvény három érték-kategóriát különböztetett meg: a hungarikumokat, a kiemelkedö nemzeti értékeket és a nemzeti értékeket.

A jogszabály szerint a hungarikum egy olyan gyüjtőfogalom, amely „egységes osztályozási, besorolási és nyilvántartási rendszerben olyan megkülönböztetésre, kiemelésre méltó értéket 
jelöl, amely a magyarságra jellemzö tulajdonságával, egyediségével, különlegességével és minöségével a magyarság csúcsteljesitménye". A törvény értelmében nemzeti érték a termelési kultúrához, a tudáshoz, a hagyományokhoz, a magyar tájhoz és élővilághoz kapcsolódó, felhalmozott és megörzött minden szellemi és anyagi, természeti, közösségi érték vagy termék, illetve a tájhoz és az élővilághoz kapcsolódó materiális vagy immateriális érték. A kiemelkedö nemzeti érték pedig olyan érték, amely nemzeti szempontból meghatározó jelentőségü, a magyarságra jellemző és közismert, jelentősen öregbíti hírnevünket, növelheti megbecsülésünket szerte a világon (HTTPS://NET.JOGTAR.HU/JOGSZABALY?DOCID=A1200030.TV).

A nemzeti értékek egy tágabb kört határoznak meg, tehát nem csak a csúcsteljesítményeket foglalják magukba, hanem mindazokat az értékeket, amik a magyarságra jellemzők. Ebből az a következtetés vonható le, hogy minden hungarikum nemzeti érték, de nem minden nemzeti érték hungarikum. A magyar nemzeti érték és a hungarikum közötti különbséget illetően azt is fontos kiemelni, hogy míg elöbbi a magyarsághoz köthető felhalmozott és megörzött szellemi, anyagi, természeti, közösségi érték vagy termék, utóbbit, azaz a hungarikumot kiemelésre méltó nemzeti értékként definiáljuk, amely jellemző tulajdonságával, egyediségével, különlegességével és minőségével a magyarság csúcsteljesítményét jelenti (TÓZSA - ZÁTORI 2013).

A törvénnyel összefüggésben megerösíthetjük és a kutatásunk szempontjából is kiinduló definícióként használjuk a következő megközelítést. „A hungarikumok csak Magyarországra jellemzö, különleges, egyedi minöségü magyar termékek, vagy csak Magyarországon megtalálható, egyedülálló természeti, vagy kulturális értékek: a csak Magyarországon megtalálható, öshonos, vagy itt nemesitett állat- és növényfaj, az országosan ismert, magyar népmüvészeti, képzömüvészeti alkotás, a különleges épitészeti alkotás, emlék, zene, nyelv és a magyar irodalom. Idetartoznak a kulturális tradicionális értékek, népi emlékek, valamint a csak Magyarországra jellemzö természeti értékek köre” (TÓZSA-ZÁTORI 2013: 9).

A hungarikum törvény utasítása alapján a végrehajtási rendelet rendelkezik arról, hogy a nemzeti értékek gyüjtése, azonosítása során ezeket milyen szakterületenkénti kategóriák szerint kell azonosítani. E szerint az azonosítás kategóriái: az agrár- és élelmiszergazdaság, az egészség és életmód, az épített környezet, az ipari és műszaki megoldások, a kulturális örökség, a sport, a természeti környezet, a turizmus és vendéglátás (2012. ÉVI XXX. TÖRVÉNY A MAGYAR NEMZETI ÉRTÉKEKRŐL ÉS A HUNGARIKUMOKRÓL, TÓZSA 2019).

A Hungarikumok Gyüjteményében jelenleg (2021 áprilisában) 76 kiemelkedő nemzeti érték szerepel. A legtöbb érték a kulturális örökség kategóriában található. A hungarikumok az egyes kategóriákban a következőképpen oszlanak meg: agrár- és élelmiszergazdaság (25 db), egészség és életmód $(5 \mathrm{db})$, épített környezet $(1 \mathrm{db})$, ipari és müszaki megoldások $(3 \mathrm{db})$, kulturális örökség ( $31 \mathrm{db})$, sport ( $2 \mathrm{db}$ ), természeti környezet ( $3 \mathrm{db})$, turizmus és vendéglátás (6 db) (HUNGARIKUMOK GYÜJTEMÉNYE).

A Hungarikum Bizottság 2013. január 31-i döntésével a hungarikum törvény erre vonatkozó III. 12. § (2) pontja alapján, azaz a törvény erejénél fogva hungarikumok az UNESCO világörökségi helyszínek és a szellemi kulturális örökség értékei is (MIK AZOK A HUNGARIKUMOK).

\section{A hungarikum törvény nemzetstratégiai jelentősége}

A Kárpát-medencei hálózati gazdaság fejlesztéséhez, a nemzetstratégiai keretprogramok megvalósításához nagymértékben hozzájárulhat a hungarikumok ügye is. A magyar nemzeti értékekről és hungarikumokról szóló törvény nemzeti megközelítésü jogszabály, amelynek 
célcsoportja és célterülete nem csupán Magyarország, hanem minden olyan közösség, amelyet magyar emberek alkotnak (TÓZSA 2019).

A hungarikum törvény 2015. évi módosításának egyik legfontosabb rendelkezése a külhoni értékgyüjtés magyarországi mintára történő megteremtése volt. Ezek alapján a Magyar Állandó Értekezleten részt vevő külhoni szervezetek a saját országuk vonatkozásában Külhoni Nemzetrész Értéktárat müködtethetnek. Emellett a külhoni önkormányzatok, jogi személyek saját országuk vonatkozásában - a Magyar Állandó Értekezletre meghívott külhoni szervezet támogatása esetén - települési, tájegységi értéktárat hozhatnak létre. A cél az, hogy az országhatáron túl is megvalósulhasson a helyi szintü értékgyüjtés, elinduljanak ott is az alulról történő kezdeményezések, és biztosítható legyen azok becsatornázása az egységes Nemzeti Értékpiramis rendszerébe. A törvénymódosítás eredményeként elindult a határon túli értékgyüjtő mozgalom aktív szerveződése. Ebben a rendszerben külön státuszt képvisel a legnagyobb külhoni magyar tömböt képviselö tájegységi értéktár, a Székelyföldi Értéktár és Értéktár Bizottság (2015. ÉVI LXXX. TÖRVÉNY A MAGYAR NEMZETI ÉRTÉKEKRŐL ÉS A HUNGARIKUMOKRÓL SZÓLÓ 2012. ÉVI XXX. TÖRVÉNY MÓDOSÍTÁSÁRÓL, TÓZSA 2019). A Hungarikum Gyüjteményben szereplö, településekhez kapcsolódó hungarikumok közül a legtöbb érték Magyarországon található, kettő kapcsolódik külhoni magyar területhez (Torockó épített öröksége, valamint a csíksomlyói pünkösdi búcsú és kegyhely) (HUNGARIKUMOK GYÜJTEMÉNYE).

\section{A hungarikumok szerepe a helyi és a nemzeti identitás formálásában}

Németh Marika azt vallja, hogy saját nemzetünk pozitív önértékelésének a feltétele, hogy csak értékes tulajdonságokkal legyen felruházva. A saját csoport felértékelése önmagunk érdekét és védelmét szolgálja és elengedhetetlen feltétele az életképes nemzettudatnak. Ehhez hozzájárulnak az egyedi helyi és nemzeti sajátosságokat képviselő hungarikumok (NÉMETH é.n.).

Nótári Márta ezt azzal egészítette ki, hogy a nemzeti érzés és identitás mintái elevenen élnek a magyar lakosság körében (NÓTÁRI 2008). Szociológiai vizsgálatok a gazdasági nacionalizmus növekedését állapították meg napjainkban. Ezek szerint az etnocentrizmus a belföldi, illetve a nemzeti piac felsőbbrendüségét feltételezi, amelynek egyik oka az, hogy egyes nemzetek fogyasztói sajátos etnocentrizmussal (az adott népre való orientációval) rendelkeznek. Az egyén ilyen típusú beállítottsága befolyásolja termékválasztását is. Nótári úgy látja, hogy a magyar lakosság körében a 60 éves és idősebb emberek fogyasztói etnocentrizmusa a legnagyobb. Ennek oka lehet, hogy idősebb korban alakulnak ki az etnocentrizmus különböző szintjei: a nemzeti identifikáció, a nemzetpreferencia. Berács József és Malota Erzsébet megjegyezték, hogy amennyiben az egyén fontosnak tartja például a magyar aranyérem megszerzését az Olimpián, valószínüsíthető, hogy a magyar termékekről is pozitívabb véleménnyel rendelkezik (BERÁCS - MALOTA 2000).

Káposzta József és kutatótársai a nemzeti identitás fontossága mellett kiemelték a lokális identitások szerepét (KÁPOSZTA et al. 2015). Megállapították, hogy a globalizáció egyik következménye a térségek, a lokalitások szerepének megváltozása és felértékelődése. Az új területi politikák következtében hazánkban is fontos szerepet kapnak a lokális, endogén erőforrások, mint az önerőből történő építkezés alapkövei. A helyi erőforrások igénybevétele biztosítja, hogy a befektetett tőke helyben marad és újrahasznosul. Emellett a helyi sokszínüség hangsúlyozása és reklámozása, a hely jellegzetességeinek támogatása, a helyi identitás, valamint a hozzákapcsolódó különféle minőségi áruk és szolgáltatások fejlesztése és értékesítése a globalizációval szembeni védelmet is jelenti.

Káposztáék kutatási eredményei igazolták, hogy a hungarikumok előállítása számos közvetlen és föleg közvetett haszonnal jár a vizsgált térségek társadalmára és gazdaságára, igaz, egyelöre 
még korlátozott mértékben. Hozzájárulnak többek között a helyben történő munkahelyteremtéshez és -megőrzéshez, az alapanyag-előállítók bevételeinek és így a helyi adóbevételeknek a növekedéséhez. Fontos megállapításuk az is, hogy az általuk tanulmányozott hungarikumok egyáltalán nem, vagy nem elég hangsúlyosan jelennek meg az érintett térségek fejlesztési terveiben. Ezért véleményük szerint nagyobb figyelmet kell fordítani ezen endogén erőforrások nemzeti és helyi fejlesztési stratégiákba való beépítésére. Az is megállapítható, hogy ezen értékeknek a helyi lakosság (és a turisták) számára történő bemutatásában jellegzetes eszközök a fesztiválok, a vásárok és a tematikus utak (TÓTH et al. 2017).

\section{A primer kutatás eredményei és összefüggései}

A kérdöíves vizsgálatot 35 olyan hungarikumnak a körében végeztük, amelyik valamely településhez kapcsolódik. A Hungarikum Gyüjteményben szereplö, településekhez és térségekhez kapcsolódó hungarikumok közül a legtöbb érték Magyarországon található, kettő kapcsolódik külhoni magyar területhez (csíksomlyói pünkösdi búcsú és kegyhely, valamint Torockó épített öröksége).

A primer kutatás során feltételeztük azt, hogy amennyiben a válaszadók véleménye szerint egyegy hungarikum jelentősebb szerepet tölt be a településfejlesztésben, abban az esetben a településen élőket is nagyobb büszkeséggel töltik el ezek az értékek. Feltételezéseink szerint az értékeknek a településfejlesztésben történő nagyobb mértékü hasznosításával az adott érték a munkahelyteremtésben és a közösségépítésben magasabb területi szinten (nem kizárólag települési, hanem regionális, országos vagy akár nemzetközi szinten) is képes hatni.

A kérdöíves vizsgálat során megkerestük azokat a települési szervezeteket, amelyek vagy a hungarikumok felterjesztéséért, vagy azok kezeléséért/menedzseléséért felelösek és felkértük öket kérdőívünk kitöltésére. A 35 felkért szervezet közül 30 töltötte ki a kérdőívet.

Azokat a szervezeteket, melyek több hungarikumot is kezelnek, arra kértük, hogy külön-külön minden értékre vonatkozóan töltsenek ki egy-egy kérdőívet. Így két kitöltött kérdőívet kaptunk a Tokaj Borvidék Fejlődéséért Nonprofit Kft-től, mely a Tokaj-hegyaljai történelmi borvidék kultúrtájjal és a borvidéken előállított tokaji aszúval kapcsolatban is kitöltött egy-egy kérdőívet. Szintén két kitöltés érkezett a Pick Szeged Zrt-től, mely a Pick téliszalámira és a Herz Classic téliszalámira vonatkozóan is töltött ki kérdőívet. A kalocsai Viski Károly Múzeum a kalocsai népmüvészettel (írás, hímzés, pingálás) és a kalocsai füszerpaprika-őrleménnyel kapcsolatban egy-egy kérdőív kitöltésével volt a segítségünkre. A Zsolnay Örökségkezelő Nonprofit Kft-től szintén két kitöltött kérdőív érkezett vissza, egyrészt a Zsolnay Kulturális Negyedre, másrészt a Pécs (Sopianae) ókeresztény temetőjére vonatkozóan. A Szegedi Paprika Fűszer- és 
Konzervgyártó Zrt. a szegedi füszerpaprika-őrleménnyel és a hízott libamájas készítményekkel kapcsolatban töltött ki egy-egy kérdöívet.

A további szervezetek mindegyike egy hungarikumra vonatkozóan töltött ki kérdöívet:

- a CsabaPark a csabai kolbászról és csabai vastagkolbászról;

- a Gyulai Turisztikai Nonprofit Kft. a gyulai kolbászról és gyulai pároskolbászról;

- a makói József Attila Városi Könyvtár és Múzeum a makói hagymáról;

- a Debreceni Értéktár Bizottság a debreceni páros kolbászról;

— az Eger Tourinform Iroda az egri bikavérről;

— a Szőregi Művelödési Központ a szőregi rózsatőről;

- a Hévíz Tourinform Iroda a Hévízi-tóról és a tradicionális hévízi gyógyászatról;

— egy szakértő Torockó épített örökségéröl;

- a Mohácsi Városszépítő és Városvédő Egyesület Idegenforgalmi és Turisztikai Szervezete a mohácsi busójárásról, a maszkos télüző szokás modelljéről;

- a Matyóföldi Idegenforgalmi Egyesület vezetője a matyó népmüvészetről, a közösség hagyományos közösség hímzéskultúrájáról;

— a Lechner Tudásközpont Kulturális Örökségvédelmi Igazgatóság a Budapest - a Duna-partok, a Budai Várnegyed és az Andrássy út világörökségről;

— a Hollókői Világörökség-kezelő Nonprofit Kft. Hollókő Ófaluról és környezetéről;

- a Pannonhalmi Főapátság az Ezeréves Pannonhalmi Bencés Főapátságról és természeti környezetéröl;

— a Hortobágyi Nemzeti Park Igazgatóság a Hortobágyi Nemzeti Park - a Pusztáról;

- a Fertö-táj Világörökség Magyar Tanácsa Egyesület a Fertö/Neusiedlersee kultúrtájról;

- a Halasi Csipke Alapítvány a halasi csipkéröl;

- a Vizsolyi Református Egyházközség a Vizsolyi Bibliáról;

- egy szakértő a csíksomlyói pünkösdi búcsúról és kegyhelyről;

— az Aggteleki Nemzeti Park Igazgatóság az Aggteleki-karszt és a Szlovák-karszt barlangjairól;

— a Karcagi Birkafözők Egyesülete a karcagi birkapörköltröl;

- a Bajai Települési Értéktár Bizottság a bajai halászléről.

A kérdöívek kitöltésére 2021. február 11. és március 16. között került sor.

A kérdőívek értékelésekor csoportokat képeztünk az azonos kategóriába tartozó, azonos jegyekkel bíró hungarikumokból. Ezáltal jobban vizsgálhatóvá válhattak egyrészt a csoportokon belüli hasonlóságok, másrészt a csoportok közötti különbségek. Az egyes alfejezetek részfejezeteiben ezen csoportosítás alapján külön elemeztük az UNESCO világörökség listára természeti és kulturális kategóriában felkerült világörökségi értékek, az agrár-és élelmiszeripari termékek, illetve az egyéb kulturális örökségek települési és térségi identitásra gyakorolt hatásait.

A világörökségeknek külön kategóriaként való kezelése indokolt egyrészt az értékek kiemelkedö volta miatt, másrészt azért, mert a mintában jelentős arányban jelennek meg a világörökségek, amelyek a vizsgált 30 hungarikumnak csaknem a harmadát teszik ki (8 érték - 27\%). A világörökségek közé sorolható a Budapest - a Duna-partok, a Budai Várnegyed és az Andrássy út, a Hollókő Ófalu és táji környezete, a Pannonhalmi Főapátság, a Fertőtáj világörökség, Pécs Sopianae ókeresztény temetője, valamint a Hortobágyi Nemzeti Park - a Puszta, az Aggteleki- és a Szlovák-karszt barlangjai és a Tokaj-hegyaljai történelmi borvidék kultúrtáj. Ezek az értékek 
együttesen a Hungarikum Gyüjteménynek a kulturális örökség és természeti környezet kategóriájába tartoznak.

Az élelmiszeripari termékek a mintánkban szereplö hungarikumok legnagyobb arányát teszik ki (12 érték - 40\%). Ebben a csoportban elemeztük a Hungarikum Gyüjteményben az agrár- és élelmiszergazdaság, valamint a turizmus és vendéglátás kategóriába besorolt termékeket is. Ide sorolhatók a szegedi paprika, a hízott libamájas termékek, a kalocsai füszerpaprika, a csabai kolbász, a tokaji aszú, a debreceni pároskolbász, a makói hagyma, a Herz és a Pick téliszalámi, az egri bikavér, valamint a karcagi birkapörkölt és a bajai halászlé.

A kulturális örökségekhez soroltuk a Hungarikum Gyüjteményben kulturális örökség kategóriában szereplö - a fent említett világörökségeken kívül szereplő - értékeket (ide értve az emberiség szellemi kulturális örökségének reprezentatív listáján lévő értékeket is), valamint az épített környezet kategóriába sorolt értékeket. Ebben a csoportban vettük górcső alá a szőregi rózsát, a Vizsolyi Bibliát, a matyó népmüvészetet, a kalocsai népművészetet, a halasi csipkét, a Hévízi tófürdőt, a csíksomlyói búcsút, a mohácsi busójárást, a torockói épített örökséget és a Zsolnay Kulturális Negyedet (10 érték). Ezek az értékek a jelen vizsgálati minta harmadát, 33\%át teszik ki.

Elsőként a megkérdezettek arra adtak választ, hogy a hungarikum mennyire meghatározó tényezöje a településfejlesztésnek, hogyan viszonyul a település vezetése a hungarikumhoz.

A három kategóriát összehasonlítva megállapítható, hogy leginkább az élelmiszeripari termékek hasznosítása valósul meg jelentős mértékben a településfejlesztésben: ezt jelezte a válaszadók 92\%-a. A világörökségek esetében azt feltételeztük, hogy ezek az élelmiszeripari termékekhez hasonló mértékben épülnek be a településfejlesztésbe, azonban a feltételezett eredményhez képest azt tapasztaltuk, hogy a válaszadóknak csak a fele része jelezte azt, hogy a település vezetése jelentős mértékben vonná be ezeket az értékeket a településfejlesztésbe. Tanulságos volt számunkra az, hogy ezek a világ minden nemzete számára vonzerőt jelentő értékek vajon miért nem jelennek meg hangsúlyosabban adott településfejlesztési eszközrendszerben. Ugyancsak a kulturális örökségekkel kapcsolatban a megkérdezettek fele ítélte meg úgy, hogy azok jelentős mértékben jelennek meg a településfejlesztésben. A pozitív vélemények mellett azonban a világörökségek és az élelmiszeripari termékek esetében a kevésbé pozitív megítélést jelző vélemények viszonylag magas aránya (a válaszok harmada illetve a fele része) mindkét termékcsoport esetében a települési marketing tevékenység és a településfejlesztés ez irányú elömozdítására hívhatja fel a figyelmet. Az elemzések azt is megmutatták a világörökségek és a kulturális örökségek esetében, hogy a lakossági viszonyulás még így is pozitívabb ezen értékek iránt, mint azok bevonása a településfejlesztésbe. Ebben az élelmiszeripari termékek jelentenek kivételt, mert a települési hasznosításuk jelentősebb mértékü, mint a lakossági megítélésük.

Arra is kerestük a választ, hogy a válaszadók hogyan vélekednek azzal a kérdéssel kapcsolatban, hogy a lakosság hogyan viszonyul ezekhez az értékekhez, mennyire büszkék ezekre az értékekre.

A három csoportban szereplő hungarikumokat összehasonlítva az volt kimutatható, hogy a kulturális örökségekkel kapcsolatban a legpozitívabb a lakossági megítélés. Ezeknél a válaszadók 80\%-a mondta azt, hogy a lakosságot büszkeséggel töltik el ezek az értékek. Ezt követte az élelmiszeripari termékek megítélése. Esetükben a megkérdezettek 67\%-a vélte úgy, hogy a lakosság pozitívan viszonyul ezekhez az értékekhez. Ez után következtek csak a világörökségek, ami a településfejlesztésben való megjelenés kérdésköréhez hasonlóan tanulságos eredményt hozott. Ennél ugyanis pozitívabb megítélést, nagyobb büszkeségérzést feltételeztünk előzetesen a lakossági megítélés tekintetében. Itt a válaszadók fele látta úgy, hogy a lakosságot büszkeséggel töltik el a világörökségek, a vélemények másik fele viszont azt 
tükrözte, hogy az itt élők közepesen vagy kevésbé tartják fontosnak ezeket a kiemelkedő értékeket.

A következő vizsgálati kérdéskör során a válaszadóknak a vállalkozásokra, a civil szervezetekre, a közösségekre gyakorolt hatások területi szintjét (települési, regionális, országos, nemzetközi) kellett azonositani.

A hungarikumok összesített elemzésével az igazolódott, hogy azon értékek esetében, amelyek a munkahelyekre, a vállalkozásokra országos illetve regionális szinten fejtenek ki hatást, a megkérdezettek többségében úgy látták, hogy a hungarikum meghatározó tényezője a településfejlesztésnek és általában az ott élöket is büszkeséggel töltik el ezek az értékek. A munkahelyekre, a vállalkozásokra települési szinten hatást gyakorló hungarikumoknak azonban csak a 40 százalékáról mondható el az a megkérdezettek szerint, hogy meghatározó tényezője a településfejlesztésnek, emellett megoszlik a településen élőknek az értékhez való viszonyulása is. A vállalkozásokra nemzetközi szinten hatást gyakorló hungarikumok a településfejlesztési programokban változóan vannak jelen: a budapesti és a hévízi helyszín kiválóan és jól, a szőregi rózsának a településfejlesztésben betöltött szerepe azonban „közepesre” tehető. Ugyanakkor a településen élök inkább büszkeséggel viszonyulnak ezekhez az értékekhez.

Azokkal a hungarikumokkal kapcsolatban, amelyek a civil szervezetekre és a közösségekre nem gyakorolnak hatást, megállapítható, hogy a vállalkozásokra sem gyakorolnak, vagy legfeljebb csak települési szinten gyakorolnak hatást. Az adatelelemzések során látható volt az is, hogy azok a hungarikumok, amelyek települési vagy regionális szinten gyakorolnak hatást a civil szervezetekre és a közösségekre, kevés kivétellel a vállalkozásokra is települési vagy regionális szinten fejtik ki hatásukat. Azoknál az értékeknél, melyek országos és nemzetközi szinten gyakorolnak hatást a civil szervezetekre és a közösségekre, a vállalkozásokkal kapcsolatban is inkább a kiterjedtebb, regionális, országos, illetve nemzetközi szintü hatások jelennek meg.

A három kategóriába tartozó hungarikumokat is összehasonlitottuk az értékeknek a vállalkozásokra és a közösségekre gyakorolt hatásai szintje szempontjából.

Itt az nyert megállapítást, hogy az élelmiszeripari termékek leginkább országos szinten fejtik ki hatásukat a vállalkozásokra, ezt igazolta vissza a válaszadóknak a harmada. A kulturális örökségek leginkább regionális szinten fejtenek ki hatást a vállalkozásokra a válaszadók többsége (40\%) szerint, míg a világörökségek esetében a válaszadók fele része a lokális, települési szintü hatást említette.

A közösségszervezés tekintetében a világörökségeknek országos vagy nemzetközi szinten kifejtett hatását emelhetjük ki. Ebben a tekintetben meghatározó az UNESCO világörökség programja, amely biztosítja a világörökségek számára a nemzetközi szintü jelenlétet. Ez a program arra irányul, hogy az emberiség kulturális és természeti örökségét nyilvántartásba vegye, s így azoknak az országoknak, amelyek erre a listára kerülnek, vállalniuk kell, hogy megóvják a területükön lévő világörökségi helyszíneket, hogy aztán a későbbi generációk is élvezhessék azok szépségét. Ezzel a felelősséggel is indokolható tehát a világörökségi helyszínek által generált országos és nemzetközi szintü közösségi hatás.

A világörökségeket követik az elsösorban települési szintü hatást gyakorló kulturális örökségek. Ezek az értékek annak ellenére települési szinten fejtenek ki elsősorban hatást a közösségekre, hogy az UNESCO az egyezményében átfogó, nemzetközi elveket fogalmaz meg az ebben a csoportban is szereplő szellemi kulturális örökségek megőrzése érdekében, és saját eszközeivel segíti ezek helyi, nemzeti és nemzetközi szintű elismertetését. A települési szinten kifejtett hatások magyarázata leginkább abban rejlik, hogy a települési örökségértékek megőrzésében, a helyi identitás és a hozzájuk kapcsolódó különféle szolgáltatások fejlesztésében meghatározó 
szerepe van a kulturális örökség kategóriában felülreprezentált népi hagyományoknak, amelyek elsősorban lokális szinten határozzák meg a hagyományok továbbélését.

Végül az élelmiszeripari termékek emlithetök, amelyek bár elsösorban települési és regionális szinten fejtik ki közösségi hatásukat, azonban a vélemények jelentös része (harmada) tükrözte a viszonylag gyenge közösségépítő potenciált. Az élelmiszeripari termékek közösségszervező képességében a válaszadók szerint tehát sokkal több lehetőség rejlik, mint amennyit eddig abból ki tudtak használni. Ezt részben indokolja az is, hogy föként a turizmus és vendéglátás kategóriában szereplö termékek (bajai halászlé, karcagi birkapörkölt), valamint az élelmiszeripari termékek között szereplő borok (tokaji aszú, egri bikavér) és a csabai kolbász esetében beszélhetünk jelentősebb közösségszervező tényezőről, hiszen ezekre a termékekre épültek elsősorban közösségi rendezvények és hagyományőrző programok. Ezekre a „megalkotott hagyományokra" szükségük van a települési közösségeknek, hiszen ezek befolyásolják leginkább a lakosság identitását és a közösségek épülését. A gasztronómiai fesztiválok célja ugyanis a megelevenedett kultúra révén a tradíciók megőrzése, a közösség formálása, hiszen az együtt étkezés fontos közösségépítő tényező, így az identitás is formálható általa. Ugyanakkor az látható, hogy a kutatás mintavételében ezek a termékek az élelmiszergazdasági kategóriába sorolt értékeknek valójában mindössze a harmadát teszik ki.

A vizsgálatunk során arra is kitértünk, hogy adott településen a hungarikumok milyen mértékü hatást gyakorolnak a munkahelyteremtésre, a hungarikumra épülö vállalkozásokra, a települési önkormányzat, a vállalkozások és a civil szervezetek között kialakult együttmüködésekre.

A korábbi adatelemzések során a világörökségekkel kapcsolatban megkérdezett szervezetek jelölték meg legnagyobb arányban azt, hogy azok települési szinten gyakorolják a legjelentősebb hatást a munkahelyteremtésre, a vállalkozások müködésére. Visszatérve a jelen vizsgálati kérdéskörre, szintén az látható, hogy a világörökségek települési szinten magukat jelentősebb (50\%) munkahelyteremtő potenciállal és képességgel értékelték, mint a kulturális örökségek és az élelmiszeripari termékek. A világörökségeket követték a kulturális örökségek (30\%), majd pedig az élelmiszeripari termékek munkahelyteremtő képességére utaló válaszok (17\%). A három csoport közül feltünhet számunkra az élelmiszeripari termékek települési munkahelyteremtésre gyakorolt hatásainak alulértékelése, illetve itt láthatók a szubjektív véleményekből adódó ellentmondásos válaszok is. Ezt mutatja többek között az a megítélés is, amely szerint a magát kismértékü vagy közepes települési munkahelyteremtő hatást kifejtő kategóriába soroló tokaji aszú és egri bikavér valójában nagyobb teljesítményt nyújt, mint a magát nagyobb települési munkahelyteremtő hatást kifejtő kategóriába helyező termékek.

Mindhárom csoport válaszadói többségének tehát az a véleménye, hogy a hungarikumok viszonylag kismértékü hatást gyakorolnak a települések munkahelyteremtésére. A kismértékü munkahelyteremtő képességet hangsúlyozó jelentős többség (az élelmiszeripari termékek esetében a válaszadók kétharmada, a világörökségek esetében a válaszadók fele része, a kulturális örökségek esetében a válaszadók 40\%-a) véleménye felhívhatja az értékek kezelőinek figyelmét az ebből a helyzetből származó lehetőségek hatékonyabb kihasználására is.

A kismértékü munkahelyteremtő képesség azonban nem jelenti azt, hogy ezek az értékek ne gyakorolnának hatást a települési együttmüködésekre és a közösségekre. Mindhárom csoport 
esetében kimutatható volt az, hogy ezek az értékek jelentősebb hatást gyakorolnak a települési együttmüködésekre és a közösségépitésre, mint a munkahelyteremtésre.

A vállalkozások számára, a foglalkoztatás mértékére és a vállalkozásokból származó bevételnek az éves bevételhez való hozzájárulására vonatkozóan az alábbi eredményeket emeljük ki.

Az élelmiszeripari termékek esetében a válaszadók legnagyobb aránya (50\%) jelölte meg az 110 közötti számú vállalkozást, ami nagyobb arány, mint amit a világörökségek esetében $(25 \%)$, vagy amit a kulturális örökségek esetében (30\%) jeleztek a válaszadók. Mindamellett a válaszadók mindhárom esetben a legnagyobb arányban említették az 1-10 közötti számú vállalkozásokat az egyes településeken.

A világörökségek között a legtöbb vállalkozás a budapesti világörökségi együttesen és a tokaji borvidéken jelenik meg és ez a két helyszín segíti elő a legtöbb ember foglalkoztatását is. Az élelmiszeripari termékek között a legtöbb vállalkozás a tokaji aszúval kapcsolatban mutatható ki és ezek a vállalkozások foglalkoztatják a legtöbb munkaerőt. A kulturális örökségek között a legnagyobb foglalkoztató a Hévízi-tó és ehhez kapcsolódik a legtöbb vállalkozás is.

A települési hatások vizsgálata mellett azt is megkérdeztük az érintettektől, hogyan és milyen mértékben hat a hungarikum az érintett térség (megye) munkahelyteremtésére, a vállalkozások ösztönzésére és az együttmüködésekre.

A három csoport összehasonlításával azt a következtetést vonhatjuk le, hogy az élelmiszeripari termékek nagyobb mértében fejtenek ki gazdasági hatást térségi szinten, mint a világörökségek és a kulturális örökségek. Települési szinten a világörökségek kerültek az első helyre, majd őket követték a kulturális örökségek és végül az élelmiszeripari termékek következtek.

Az élelmiszeripari termékek esetében a válaszadók harmada vallotta azt, hogy jelentős mértékben járulnak hozzá a térségi munkahelyek létrehozásához és a válaszadók fele része mondta azt, hogy adott termék kis vagy közepes mértékben járul hozzá a térségi munkahelyteremtéshez. Ugyanakkor a világörökségek esetében a válaszadók negyede mondta azt, hogy jelentős mértékben járulnak hozzá a munkahelyteremtéshez, míg kétharmada válaszolta azt, hogy kevésbé járulnak hozzá a munkahelyteremtéshez. A kulturális örökségek esetében a válaszadók 20\%-a tett említést jelentősebb, harmaduk közepes mértékü és $40 \%$-uk kismértékü térségi gazdasági hatásokról.

A válaszok többsége tehát a kismértékü térségi gazdasági hatást támasztotta alá (az élelmiszeripari termékek esetében a válaszok fele része, a világörökségek esetében a válaszok kétharmada, a kulturális örökségek esetében a válaszok $60 \%$-a). Ezek a vélemények azt erősítették meg, hogy ezeknek az értékeknek a munkahelyteremtő lehetőségeit még kevésbé használták ki térségi szinten, mint azt települési szinten tapasztalhattuk. Ha tehát a térségi gazdasági hatásokat mindhárom csoportban összevetjük a településre gyakorolt hatásokkal, akkor azt látjuk, hogy jelentösebb a települési, mint a térségi munkahelyteremtö hatás mindhárom csoport esetében.

A térségi együttmüködésekkel kapcsolatban is az igazolódott, hogy a hungarikumok jelentősebb együttmüködést ösztönző erővel rendelkeznek, mint amennyire a munkahelyteremtéshez hozzájárulnak térségi szinten. Ezt igazolta az élelmiszeripari termékek esetében a megkérdezettek harmada, akik szerint az élelmiszeripari termékek térségi szinten jelentős együttmüködést generáló tényezők, ugyanakkor $67 \%$-uk elsősorban települési szinten gyakorol jelentős hatást az együttmüködésekre. A világörökségek esetében is hasonló eredmény született: itt a válaszadók harmada mondta azt, hogy ezek térségi szinten jelentős együttmüködést ösztönző tényezők, a válaszadók 63\%-a azonban azt igazolta vissza, hogy a világörökségek elsősorban települési szinten fejtenek ki jelentősebb hatást az együttmüködésekre. A legjelentősebb mértékben a kulturális örökségek gyakorolnak hatást a térségi és a települési együttmüködésekre. Ezeknél a válaszadók 
fele része mondta azt, hogy a kulturális örökségek jelentős mértékben járulnak hozzá a térségi együttmüködésekhez, a válaszadók kétharmada szerint viszont elsősorban települési szinten járulnak hozzá az együttmüködések kialakításához. Itt is azt a megállapítást emelhetjük ki tehát mindhárom csoport esetében, hogy jelentösebbek az együttmüködésekre gyakorolt hatások települési szinten, mint térségi szinten.

Arra a kérdésre is kerestük a választ, hogyan és milyen eszközökkel lehetne nagyobb mértékben hasznositani a hungarikumot a települési identitás erösitése érdekében.

A világörökségek csoportjában a válaszadók kiemelték az érintett önkormányzatok, vállalkozások és civil szervezetek együttmüködésének erösítését és a világörökségek fejlesztési programjának integrálását a támogatási rendszerekbe. A fiatalok megszólítása, az értékek átörökítése és az oktatásba történő integrálása is megjelent a javaslatok között. Külön fejezetet kapott a települési/térségi marketing tevékenység ösztönzése és ehhez kapcsolódóan a normatív alapú marketing célú támogatások szükségessége, valamint a kommunikációs eszközök kialakítása emelhető ki (reklám és média eszközök, kiadvány, holnap, közösségi identitásépítő rendezvények).

Az élelmiszeripari termékek között több válaszadó a támogatások jelentőségét hangsúlyozta. Ebben a válaszcsoportban az egységes minőségbiztosítást, a védjegyrendszer kidolgozását, a hungarikum termékvédelmi örökségmegőrző pályázatokat, az örökségőrök személyi támogatását, az örökség örhelyek támogatását emelték ki az érintettek. Ugyancsak felmerült a nagy kézi munkaerőt igénylö tevékenységek nagyobb arányú támogatásának szükségessége. A válaszok harmadik kategóriája a turizmusban való hasznosítás lehetőségét emelte ki. A válaszadók itt tettek említést egy termék manufaktúra létrehozásáról, ahol a termék múltjának és a gyártás teljes folyamatának bemutatása valósulhatna meg kóstolással, vásárlási lehetőséggel. A marketing témán belül a regionális szintü kommunikációs eszközök, a többnyelvü kiadványok és imázsfilm, az online kommunikációs eszközök kialakítása, a kiállításokon való részvétel és az identitásformáló rendezvények szervezése is megjelent a válaszok között.

A kulturális örökségekkel kapcsolatban felmerült egy minőségi tanúsítvánnyal ellátott hungarikum bolthálózat létrehozásának gondolata. A hungarikumok hasznosítását vonzerőfejlesztéssel (tárgyi és szellemi örökségét őrző és bemutató múzeum létrehozása) és a folyamatos marketingkommunikációs tevékenységgel (média- és reklám eszközök, kiadványok, ismeretterjesztő programok, népfőiskola, táborok, konferenciák, továbbképzések, a fiatalokat is bevonó rendezvények, interaktív programok) is lehetne növelni. A megkérdezett szervezetek fontosnak tartják, hogy ezekkel az értékekkel már kisgyermekkorban (óvodában, általános iskolában) megismerkedjenek a gyermekek, hiszen ez hosszú távon erősítheti a település megtartó erejét, és elősegítheti azt, hogy a fiatalok a szülöföldjükön maradjanak.

\section{Összefoglalás és következtetések}

A szakirodalmi kutatások rávilágítottak arra, hogy a hungarikumok hangsúlyos szerepet töltenek be az életképes nemzettudat kialakításában, hiszen nemzetünk pozitív önértékelésének egyik feltétele az, hogy lehetőleg értékes tulajdonságokkal legyen felruházva. A magyar lakosság körében elevenen élő nemzeti érzés és a nemzeti identitásminták mellett azonban kiemelhető a hungarikumoknak a lokális identitásban betöltött szerepe is. Azok ugyanis különleges, autentikus értéket képviselnek. A hungarikumok a vidéki térségek számára kitörési lehetőséget jelentenek, a városok esetében pedig a sokszínü kínálat kialakításában kaphatnak jelentős szerepet. A hungarikumok megörzése és hasznosítása számos közvetlen és föleg közvetett haszonnal jár a vizsgált térségek társadalmára és gazdaságára nézve. Hozzájárulnak többek között a helyben 
történő munkahelyteremtéshez és -megőrzéshez, az alapanyag-előállítók bevételeinek és így a helyi adóbevételeknek a növekedéséhez.

Ezeknek az értékeknek a helyi lakosság és a turisták számára történő bemutatásában bevált eszközök a fesztiválok, a vásárok és a tematikus utak. A megelevenedett kultúra révén lehetővé válik a tradíciók megőrzése, a közösségfejlesztés, és az identitás is formálható általa. Másrészt az aktív részvétel, a bevonódás következtében az autentikus értéket képviselő kínálat iránt egyre nagyobb az igény a fogyasztói oldalon. Ez pedig a települések számára gazdasági haszonnal és a települési infrastruktúra fejlődésével járhat együtt.

A kérdőíves vizsgálat során arra kerestük a választ, hogy a hungarikum mennyire meghatározó tényező a településfejlesztésben; hogyan viszonyul az adott hungarikumhoz a település vezetése és hogyan a lakosság. Az érintett szervezetektöl azt is megkérdeztük, hogy a hungarikum milyen területi szinteken (települési, regionális, országos, nemzetközi) gyakorol hatást a munkahelyteremtésre és a közösségekre, illetve milyen mértékben fejt ki hatást a munkahelyteremtésre, a vállalkozásokra és az együttmüködésekre az adott településen, illetve az adott térségben. A vizsgálatunk végül kitért arra is, hogyan és milyen eszközökkel lehetne nagyobb mértékben hasznosítani a hungarikumot a település fejlődésének elősegítése és a településen élők identitásának erősítése érdekében.

A primer kutatás során kiderült, hogy az értékeknek a településfejlesztésben való hasznosítása összefüggést mutat az értékek megítélésével. A települések vezetésének pozitív attitüdje az értékek hasznosításával kapcsolatban befolyásolhatja a lakossági megítélést is. Azokon a településeken ugyanis, ahol a település vezetése nagy figyelmet fordít ezen értékek hasznosítására, ott láthatóan pozitívabb megítélés és nagyobb büszkeségérzés tapasztalható a lakosság részéről is.

Ezzel kapcsolatban felmerülhet bennünk az a kérdés, hogy vajon miért lehet büszkébb a lakosság a kulturális örökségekre, mint az emberiség kiemelkedő kincseit jelentő világörökségekre. Ehhez érdemes figyelembe vennünk azt, hogy a kulturális örökség csoportban zömében olyan értékek találhatók, amelyek szerepelnek az UNESCO szellemi kulturális örökségek reprezentatív listáján. Ide sorolható a mohácsi busójárás, a kalocsai népmüvészet, a matyó népművészet, a halasi csipke is. A fenti kérdés magyarázata az lehet, hogy ezek az értékek az élő közösségek tudásaként továbbörökített kulturális megnyilvánulások, amelyek ma is erőteljesen meghatározzák az érintett közösségek, csoportok és egyének identitását, miközben ezeket a kifejezési formákat, a közös tudást elismerik a saját kulturális örökségükként. Ez a közös(ségi) tudás jelentős mértékben segítheti az adott település megtartó erejét és erőforrásokat biztosíthat egy közösség továbbéléséhez.

A hungarikumok összesített elemzésével bizonyítást nyert az, hogy adott értéknek a hangsúlyosabb megléte a településfejlesztésben általában azt is eredményezi, hogy az kiterjedtebb területi szinten gyakorol hatást a munkahelyteremtésre, a vállalkozásokra, $\mathrm{s}$ jellemzően pozitívabb a velük kapcsolatos lakossági megítélés is. Ezek szerint az élelmiszeripari termékek elsősorban országos szinten, a kulturális örökségek regionális szinten, a világörökségek föként települési szinten gyakorolnak hatást a munkahelyteremtésre és a vállalkozások ösztönzésére. A közösségépítésben azonban a világörökségek és a kulturális örökségek járnak az élen. Kiderült az is, hogy a válaszadók harmadának a véleménye szerint az 
élelmiszeripari termékek közösségszervező képességében sokkal több lehetőség rejlik, mint amennyit eddig abból kihasználtak.

\section{Irodalomjegyzék}

BERÁCS, J. - MALOTA E. (2000): Fogyasztói etnocentrizmus: az etnocentrizmus és az országeredet-imázs kapcsolata a termékválasztásban. Vezetéstudomány - Management and Business Journal 31(4): pp. 25-38.

KÁPOSZTA J. - RITTER K. - KASSAI ZS. (2015): Hungarikumok területi jelentőségének vizsgálata, különös tekintettel a pálinkára. Tér és Társadalom 29(4): pp. 139-153.

MAGYARORSZÁG ALAPTÖRVÉNYE, 2011. ÁPRILIS 25. Elérés: https://net.jogtar.hu/jogszabaly?docid=a1 100425.atv (Letöltve: 2020. december 15.)

NÉMETH M. (é.n.): A magyar nemzeti autosztereotípia átalakitása. Társadalmi Konfliktusok Kutatóközpont.

Elérés: http://konfliktuskutato.hu/index.php?option=com_content\&view=article\&id=271:a-magyarnemzeti-autosztereotipia-atalakitasa\&catid=30:nemzetek-europaja (Letöltve: 2021. január 11.)

NÓTÁRI M. (2008): A kertészeti- és élelmiszeripari hungarikum termékek primer vizsgálata, különös tekintettel a Dél-alföldi Régióra. PhD disszertáció. Tájépítészet és Döntéstámogató Rendszerek Doktori Iskola. Budapesti Corvinus Egyetem, Budapest.

SZABÓ J. (2012): A hungaricumtól a hungarikumig. Érzelmi érdekviszonyok. XXI. SzázadTudományos Közlemények 28. Általános Vállalkozási Főiskola, Budapest. pp. 111-120.

TÓTH B. - NAGY GY. - HEGEDÜS G. (2017): A helyi értékek és hungarikumok turisztikai attrakcióvá való fejlesztési lehetőségei alföldi példákon keresztül. Turisztikai és Vidékfejlesztési Tanulmányok 2(2): pp. 4-19.

TÓZSA I. - ZÁTORI A. (2013): Hungarikumok. Turizmus-vendéglátás szakos BA hallgatók részére. Budapesti Corvinus Egyetem Gazdálkodástudományi Kar, Környezettudományi Intézet, Gazdaságföldrajz és Jövőkutatás Tanszék, Turizmus Kompetencia Központ, Budapest. TÓZSA I. SZERK. (2019): Hungarikumok és nemzeti értékvédelem. Első egyetemi tankönyv. Nemzeti Közszolgálati Egyetem, Államtudományi és Közigazgatási Kar, Vezető- és Továbbképzési Központ. Dialóg Campus Könyvkiadó, Budapest.

ZENTAI A. (2015): Nemzeti értékeink megőrzése. A hungarikumok és a köréjük szervezödő rendezvények Magyarországon és külföldön. Szakdolgozat. Budapesti Gazdasági Főiskola, Kereskedelmi, Vendéglátóipari és Idegenforgalmi Kar, Budapest.

77/2008. (VI. 13.) OGY HATÁROZAT A HUNGARIKUMOK VÉDELMÉRÖL. Elérés: https://mkogy.jogtar.hu/jogszabaly?docid=a08h0077.OGY (Letöltve: 2021. január 11.)

2012. ÉVI XXX. TÖRVÉNY A MAGYAR NEMZETI ÉRTÉKEKRÖL ÉS A HUNGARIKUMOKRÓL. Elérés: https://net.jogtar.hu/jogszabaly?docid=a1200030.tv (Letöltve: 2021. január 7.)

114/2013. (IV. 16.) KORM. RENDELET A MAGYAR NEMZETI ÉRTÉKEK ÉS A HUNGARIKUMOK GONDOZÁSÁRÓL. Elérés: 114/2013. (IV. 16.) Korm. rendelet a 
magyar nemzeti értékek és a hungarikumok gondozásáról - Hatályos Jogszabályok Gyüjteménye (jogtar.hu) (Letöltve: 2021. január 11.)

2015. ÉVI LXXX. TÖRVÉNY A MAGYAR NEMZETI ÉRTÉKEKRÖL ÉS A HUNGARIKUMOKRÓL SZÓLÓ 2012. ÉVI XXX. TÖRVÉNY MÓDOSÍTÁSÁRÓL. Elérés: https://mkogy.jogtar.hu/jogszabaly?docid=a1500080.TV (Letöltve: 2021. január 7.)

\section{Egyéb források}

HUNGARIKUMOK GYÜJTEMÉNYE - MAGYAR ÉRTÉKTÁR. Elérés: http://www.hungarikum.hu/ (Letöltve: 2020. december 14.)

MIK AZOK A HUNGARIKUMOK? Elérés: http://www.hungarikum.hu/hu/content/mik-azokhungarikumok-0 (Letöltve: 2020. december 14.) 